\title{
EXPLOITATION SAFETY OF WATER SUPPLY SYSTEMS IN AREAS USED FOR AGRICULTURE
}

\author{
IZABELA ZIMOCH \& ANDRZEJ KUŚNIERSKI \\ Institute of Water and Wastewater Engineering, Silesian University of Technology, Poland
}

\begin{abstract}
The factors that determine safety loss in the exploitation of water supply systems (WSS) are random threats (draught, flood,) which lead to interruptions in water supply or delivery of lower quality water to the consumer, thus social and financial losses. Therefore, actions to understand these threats are major step towards a clear-cut evaluation of the safety of water supply systems.

Risk estimation and evaluation for undesirable events is especially important in case of smaller WSS located in agriculturally exploited areas. In order to support those systems, the paper proposes a simplified methodology of risk evaluation for WSS. Proposed analytical procedures utilize a universal method, i.e. a five-parameter risk matrix that considers: the probability of an undesirable effect, the exposure of the water supply systems to agricultural threats, financial effects, number of endangered consumers and the level of WSS protection from threats and their results.

The research algorithm consists of two stages of analysis that result in determination of: risk value $r_{i}$ for each water supply circuit (WSC - a subpart of WSS), a total risk value $r_{t}$ for an entire WSS and their categorization levels defined as: tolerated, controlled and unacceptable risk. The article also presents the results of practical applications of the research methodology in risk evaluation for existing water supply systems in southern Poland. These analyses were conducted for a 6-year research period (2010-2015) and concerned 4 independent WSS located in areas with intensive agricultural exploitation, including plant cultivation and animal breeding.
\end{abstract}

Keywords: water, safety, water supply system, risk, risk matrix, agriculture.

\section{INTRODUCTION}

Exploitation of both small and large water supply systems (WSS) is connected with the occurrence of undesirable random events that determine working conditions of those systems, and consequently their reliability [1], [2]. The causes of risks are present in every exploitation stage, from intake to consumers' tap, as well as in any other phase of their existence. Therefore, guarantee in providing the consumer with a high quality water lies in identification of hazard events, analysis of functionality of WSS, and evaluation of risk originating from safety loss in their exploitation [3], [4].

Some countries introduced and are introducing Water Safety Plan (WSP) which aims to guarantee proper quality of drinking water. Such plan, recommended by the World Health Organization (WHO) [5], is based on the risk management norms (PN-ISO 22000, and PNEN ISO 31000). An example of a good safety water practice is the introduction of New Approach to Protecting Drinking Water and Public Health in USA [6], which aims to draw up and implement exploitation and WSS management procedures in a way that maximizes public health protection. In countries such as: Hungary, the United Kingdom and Northern Ireland, a regulation revision has been carried out in order to force WSS administrators to implement WSP. Another example of ensuring safety in WSS were pilot projects concerning smaller water supply systems, which have been implemented to verify risk management premises and procedures in Austria, Czech Republic, Finland, Germany and Portugal [6]-[10]. Finally, an alternative to WSP is the HACCP (Hazard Analysis Critical Control Points) water quality control system, which was implemented in Iceland, Switzerland, Slovenia, Sweden and Macedonia, and other countries. The aforementioned risk management 
systems underline the significance of water intake protection zones and water quality control, as two of the most crucial elements of the risk control in a complex safety system of drinking water delivery [7], [8].

\section{BACKGROUND}

WSS situated in rural areas are exposed to the undesirable events of agricultural origin (plant cultivation, animal breeding). These generate numerous sources of chemical and biological pollution, that pose a direct threat to the quality of water resources used in water distribution. Risk identification and management for those systems allows for conducting appropriate preventive actions and construction of multi-barrier system. Thus ensures an effective water quality protection during the entire process of supplying it to the consumer.

The most common types of pollution coming from fertilization for WSS in agriculturally exploited areas are: pollution of animal origin (such as manure and slurry - used to provide nutrients to cultivated land), communal sludge, and chemical pollution (e.g. pesticides). Another factor that affects the quality of drinking water is proximity of animal breeding facilities and farmlands to water intake areas [7], [11]-[13].

Crucial problems for the safe exploitation of WSS situated in agricultural areas are: their small daily capacity, considerable technological diversity, location dispersion. All those issues determine conditions of water supply system exploitation.

Both external and internal factors that have an influence on exploitation of WSS located in agricultural areas [4], [7], [14], [15,] indicate the need to develop simple risk management method. There are many methods for risk analysis and management, but choosing the right one depends on: the scope and the purpose of the analysis, the stage of system development, the available exploitation data, and future updating possibilities. Based on literature [3], [16], [17], it is apparent that in the WSS risk analysis, the most significant method was a universal one, i.e. risk matrix [18].

Conditions of the exploitation of WSS in agricultural areas indicate that a method of danger analysis based on the risk matrix can be a valuable tool in daily management procedures. Working out a simple risk analysis method might be especially useful in Poland, where almost $93.2 \%$ of areas are covered by rural and urban/rural districts [19]. Since Poland also doesn't have any legal requirements to implement risk management systems, introduction of a simple method would ensure higher water quality. Therefore, the research methodology presented in this paper will allow for risk evaluation for WSS in agricultural areas.

\section{METHODOLOGY}

Applying the matrix method for risk evaluation in WSS exploitation requires taking into consideration many factors that determine potential dangers and linked with them consequences. This fact imposes the necessity of applying multifactorial risk matrixes in analytical procedures that include not only the probability of undesirable events and their financial consequences, but also the number of exposed consumers, exposure to danger, and the level of WSS protection from effects of such danger. The research conducted between 2010 and 2015 resulted in development of a risk assessment methodology for safety loss in WSS for every individual water intake system located in rural areas. Given the complex conditioning of WSS located in such areas, the methodology uses a five-parameter risk matrix, that covers: the probability of an undesirable effect (defined by exceeding the parametric values of Escherichia coli, coliform bacteria, general colony number in $22^{\circ} \mathrm{C}$ and permissible nitrate levels); the exposure of WSS to dangers connected with conducted agricultural activity; the number of endangered consumers; financial effects of low quality water; and the level of water supply system protection from danger. The second stage of the 
analysis determines the total risk for the entire WSS. The method has been prepared for WSS with at least 3 separate WSCs.

The prepared analytical algorithm is based on predefined numerical weights scale for individual risk assessment variables. The risk value for every WSC is determined from a risk formula modified for agricultural areas [14]:

$$
r_{i}=\frac{P \cdot E \cdot C \cdot F}{S}
$$

where: $\mathrm{P}$ - total weight connected with the probability of an undesirable event; $\mathrm{E}$ - weight connected with exposure of WSS to danger; $\mathrm{C}$-weight connected with number of endangered consumers; $\mathrm{F}$ - weight connected with a financial loss; $\mathrm{S}$ - weight connected with protecting the system from danger (monitoring, emergency intakes, clean water containers).

For the above variables, the numerical values are determined based on the abovementioned procedures, and then assigned levels based on a point scale: low $(\mathrm{L}=1)$, medium $(\mathrm{M}=2)$ and high $(\mathrm{H}=3)$. This way, eqn (1) produces a risk scale in a numerical form in the following range: $\langle 0,33 ; 81\rangle$ (Table 1 ), for values with a defined three-level risk categorisation (Table 2).

Risk variables present in eqn (1) are determined based on the following procedures.

The total point scale of the probability $(\mathrm{P})$ of an undesirable event " $i$ " is determined based on a questionnaire (Table 3). Based on frequency of occurrence of undesirable event, the point scale of the probability $\mathrm{p}_{\mathrm{i}}$ (for four defined incidents - Table 3), connected with agricultural activity, was determined. For all values $\mathrm{p}_{\mathrm{i}}$ the total point scale of the probability of an undesirable event was calculated using eqn (2):

$$
P=\sum_{i=1}^{4} p_{i} \text {. }
$$

Risk exposure level (E) evaluates the scale of exposure of water intake located in agricultural areas, taking into consideration both internal and external danger factors $e_{i}$. The assessment of a point scale of the exposure level of the intake in the research methodology is based on a questionnaire method (Table 4). This questionnaire was prepared based on a statistical analysis of the variability of the quality of groundwater sources in rural areas in southern Poland. Risk exposure level (E) is determined by the following eqn (3):

$$
E=\sum_{i=1}^{7} e_{i}
$$

The variable connected with number of people (C) to whom a low quality drinking water is delivered, has been determined based on a data gathered by the Chief Sanitary Inspectorate's. To accurately evaluate this parameter, only the classification of small water supply systems with daily efficiency not exceeding $1000 \mathrm{~m}^{3}$, was taken into the account. For this variable $(\mathrm{C})$ the following categorisation has been established with the assigned point weights:

up to 500 citizens

between 501 and 1500 citizens

over 1500 citizens

$$
\begin{aligned}
& \mathrm{L}=1 ; \\
& \mathrm{M}=2 ; \\
& \mathrm{H}=3 .
\end{aligned}
$$

The variable related to the amount of losses $(\mathrm{F})$ was determined in a similar way as parameter $(\mathrm{C})$ - using the data obtained during the period between 2010 and 2015, concerning the costs of necessary actions in case of an adverse event. Administrative costs incurred by the Sanitary-Epidemiological Station in Głubczyce during deterioration of quality of water delivered to consumers, were also included in this variable (F). The following costs categories with associated weights were adopted:

- visible organoleptic changes of water, consumers' complaints, financial losses up to $500 €$ related to the need of ensuring water supply during undesirable events: $L=1$ 
- significant, visible organoleptic changes (perceptible odor of water, increased color and turbidity), consumers' health problems, numerous complaints, information alert in regional public media, financial loss from $500 €$ up to $1000 €$ related to ensuring water supply in case of undesirable event: $\mathrm{M}=2$.

- required hospitalization of consumers exposed to drinking of low quality water, the involvement of professional emergency services, serious toxic consequences to indicator organisms, information alert in the national media, financial losses exceeding $1000 €$ related to ensuring water supply during undesirable event: $\mathrm{H}=3$.

Table 1: Five-parameter risk assessment matrix.

\begin{tabular}{|c|c|c|c|c|c|c|c|c|c|c|}
\hline \multirow{5}{*}{$\mathrm{C}$} & \multirow{5}{*}{$\mathrm{F}$} & \multicolumn{9}{|c|}{$P: L=1$} \\
\hline & & \multicolumn{9}{|c|}{$\mathrm{E}$} \\
\hline & & \multicolumn{3}{|c|}{$\mathrm{L}=1$} & \multicolumn{3}{|c|}{$\mathrm{M}=2$} & \multicolumn{3}{|c|}{$\mathrm{H}=3$} \\
\hline & & & & & & $\mathrm{S}$ & & & & \\
\hline & & $\mathrm{H}=3$ & $\mathrm{M}=2$ & $\mathrm{~L}=1$ & $\mathrm{H}=3$ & $M=2$ & $\mathrm{~L}=1$ & $\mathrm{H}=3$ & $\mathrm{M}=2$ & $\mathrm{~L}=1$ \\
\hline \multirow{3}{*}{$\mathrm{L}=1$} & $\mathrm{~L}=1$ & 0.33 & 0.5 & 1 & 0.67 & 1 & 2 & 1 & 1.5 & 1 \\
\hline & $M=2$ & 0.67 & 1 & 2 & 1.33 & 2 & 4 & 2 & 3 & 2 \\
\hline & $\mathrm{H}=3$ & 1 & 1.5 & 3 & 2 & 3 & 6 & 3 & 4.5 & 3 \\
\hline \multirow{3}{*}{$M=2$} & $\mathrm{~L}=1$ & 0.66 & 1 & 2 & 1.33 & 2 & 4 & 2 & 3 & 2 \\
\hline & $\mathrm{M}=2$ & 1.33 & 2 & 4 & 2.67 & 4 & 8 & 4 & 6 & 4 \\
\hline & $\mathrm{H}=3$ & 2 & 3 & 6 & 4 & 6 & 12 & 6 & 9 & 6 \\
\hline \multirow{3}{*}{$\mathrm{H}=3$} & $\mathrm{~L}=1$ & 1 & 1.5 & 3 & 2 & 3 & 6 & 3 & 4.5 & 3 \\
\hline & $M=2$ & 2 & 3 & 6 & 4 & 6 & 42 & 6 & 9 & 6 \\
\hline & $\mathrm{H}=3$ & 3 & 4.5 & 9 & 6 & 9 & 48 & 9 & 13.5 & 9 \\
\hline \multirow{5}{*}{$\mathrm{C}$} & \multirow{5}{*}{$\mathrm{F}$} & \multicolumn{9}{|c|}{$P: M=2$} \\
\hline & & \multicolumn{9}{|c|}{$\mathrm{E}$} \\
\hline & & \multirow{2}{*}{\multicolumn{4}{|c|}{$\mathrm{L}=1$}} & $\mathrm{M}=2$ & & & $\mathrm{H}=3$ & \\
\hline & & & & & & \\
\hline & & $\mathrm{H}=3$ & $M=2$ & $\mathrm{~L}=1$ & $\mathrm{H}=3$ & $M=2$ & $\mathrm{~L}=1$ & $\mathrm{H}=3$ & $M=2$ & $\mathrm{~L}=1$ \\
\hline \multirow{3}{*}{$\mathrm{L}=1$} & $\mathrm{~L}=1$ & 0.67 & 1 & 2 & 1.33 & 2 & 4 & 2 & 3 & 6 \\
\hline & $\mathrm{M}=2$ & 1.33 & 2 & 4 & 2.67 & 4 & 8 & 4 & 6 & 12 \\
\hline & $\mathrm{H}=3$ & 2 & 3 & 6 & 4 & 6 & 12 & 6 & 9 & 18 \\
\hline \multirow{3}{*}{$M=2$} & $\mathrm{~L}=1$ & 1.33 & 2 & 4 & 2.67 & 4 & 8 & 4 & 6 & 12 \\
\hline & $\mathrm{M}=2$ & 2.67 & 4 & 8 & 5.33 & 8 & 16 & 8 & 12 & 24 \\
\hline & $\mathrm{H}=3$ & 4 & 6 & 12 & 8 & 12 & 24 & 12 & 18 & 36 \\
\hline \multirow{3}{*}{$\mathrm{H}=3$} & $\mathrm{~L}=1$ & 2 & 3 & 6 & 4 & 6 & 12 & 6 & 9 & 18 \\
\hline & $\mathrm{M}=2$ & 4 & 6 & 12 & 8 & 12 & 24 & 12 & 18 & 36 \\
\hline & $\mathrm{H}=3$ & 6 & 9 & 18 & 12 & 18 & 36 & 18 & 27 & 54 \\
\hline \multirow{5}{*}{$\mathrm{C}$} & \multirow{5}{*}{$\mathrm{F}$} & \multicolumn{9}{|c|}{$\mathrm{P}: \mathrm{H}=3$} \\
\hline & & \multicolumn{9}{|c|}{$\mathrm{E}$} \\
\hline & & & $\mathrm{L}=1$ & & & $\mathrm{M}=2$ & & & $\mathrm{H}=3$ & \\
\hline & & & & & & $\mathrm{S}$ & & & & \\
\hline & & $\mathrm{H}=3$ & $M=2$ & $\mathrm{~L}=1$ & $\mathrm{H}=3$ & $M=2$ & $\mathrm{~L}=1$ & $\mathrm{H}=3$ & $\mathrm{M}=2$ & $\mathrm{~L}=1$ \\
\hline & $\mathrm{L}=1$ & 1 & 1.5 & 3 & 2 & 3 & 6 & 3 & 4.5 & 9 \\
\hline $\mathrm{L}=1$ & $\mathrm{M}=2$ & 2 & 3 & 6 & 4 & 6 & 12 & 6 & 9 & 18 \\
\hline & $\mathrm{H}=3$ & 3 & 4.5 & 9 & 6 & 9 & 18 & 9 & 13.5 & 27 \\
\hline & $\mathrm{L}=1$ & 2 & 3 & 6 & 4 & 6 & 12 & 6 & 9 & 18 \\
\hline$M=2$ & $M=2$ & 4 & 6 & 12 & 8 & 12 & 24 & 12 & 18 & 36 \\
\hline & $\mathrm{H}=3$ & 6 & 9 & 18 & 12 & 18 & 36 & 18 & 27 & 54 \\
\hline & $\mathrm{L}=1$ & 3 & 4.5 & 9 & 6 & 9 & 18 & 9 & 13.5 & 27 \\
\hline $\mathrm{H}=3$ & $\mathrm{M}=2$ & 6 & 9 & 18 & 12 & 18 & 36 & 18 & 27 & 54 \\
\hline & $\mathrm{H}=3$ & 9 & 13.5 & 27 & 18 & 27 & 54 & 27 & 40.5 & 81 \\
\hline
\end{tabular}


Table 2: Risk categories.

\begin{tabular}{|l|l|l|}
\hline Risk category & Numerical value according to eqn (1) & $R_{i}$ point scale \\
\hline Tolerated & $0.33 \leq \mathrm{r} \leq 6.0$ & 1 \\
\hline Controlled & $8.0 \leq \mathrm{r} \leq 18.0$ & 2 \\
\hline Unacceptable & $24 \leq \mathrm{r} \leq 81$ & 3 \\
\hline
\end{tabular}

Table 3: The point scale of the probability of an undesirable event connected with agricultural activity.

\begin{tabular}{|c|c|c|}
\hline$p_{i}$ & \multicolumn{2}{|c|}{ Category of undesirable event and the point scale of the probability of its occurrence } \\
\hline 1 & $\begin{array}{cl}\text { Presence of coliform bacteria in intakes } \\
- & \text { Not observed } \\
- & \text { Observed once in two years } \\
- & \text { Observed more than once in two years }\end{array}$ & $\begin{array}{l}1 \mathrm{pt} \\
3 \mathrm{pt} \\
5 \mathrm{pt}\end{array}$ \\
\hline 2 & $\begin{array}{c}\text { Presence of Escherichia Coli bacteria in intakes } \\
-\quad \text { Not observed } \\
-\quad \text { Observed once in five years } \\
-\quad \text { Observed more than once in five years }\end{array}$ & $\begin{array}{r}1 \mathrm{pt} \\
5 \mathrm{pt} \\
10 \mathrm{pt}\end{array}$ \\
\hline 3 & $\begin{array}{c}\text { Presence of a number of colonies in } 22^{\circ} \mathrm{C} \\
-\quad \text { Not observed } \\
-\quad \text { Observed once in a year } \\
-\quad \text { Observed more than once in a year }\end{array}$ & $\begin{array}{l}1 \mathrm{pt} \\
3 \mathrm{pt} \\
5 \mathrm{pt}\end{array}$ \\
\hline 4 & $\begin{array}{cl}\text { Exceeded acceptable concentration of nitrates }(50 \mathrm{n} \\
- & \text { Not observed } \\
- & \text { Observed once in five years } \\
- & \text { Observed more than once in five years }\end{array}$ & $\begin{array}{l}\left.\mathrm{g} / \mathrm{dm}^{3}\right) \\
1 \mathrm{pt} \\
3 \mathrm{pt} \\
5 \mathrm{pt}\end{array}$ \\
\hline & $\begin{array}{l}\text { sification criteria for undesirable event probability: } \\
\in\langle 4,8\rangle \quad \text { not probable } \\
\in\langle 9,13\rangle \quad \text { moderately probable } \\
\in\langle 14,20\rangle \quad \text { probable }\end{array}$ & $\begin{array}{l}L=1 \\
M=2 \\
\quad H=3\end{array}$ \\
\hline
\end{tabular}

Table 4: The point scale of exposure to the agricultural danger.

\begin{tabular}{|c|c|}
\hline$e_{i}$ & The level of intake's exposure to the agricultural danger \\
\hline 1 & $\begin{array}{l}\text { What is the well's depth? } \\
\text { to } 10 \mathrm{~m} \quad-6 \mathrm{pt} \quad \text { from } 10 \mathrm{~m} \text { to } 30 \mathrm{~m} \quad-3 \mathrm{pt} \quad \text { above } 30 \mathrm{n}\end{array}$ \\
\hline \multirow[t]{2}{*}{2} & The distance between the well and cultivated land: \\
\hline & to $0.5 \mathrm{~km}-6 \mathrm{pt} \quad$ from $0.5 \mathrm{~km}$ to $3 \mathrm{~km}-3 \mathrm{pt}$ \\
\hline 3 & 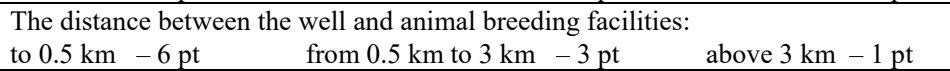 \\
\hline 4 & $\begin{array}{l}\text { Is sewage communal sludge used in order to increase soil fertility on cultivated land } \\
\text { neighbouring water intake? } \\
\begin{array}{ll}\text { yes }-3 \text { pt. } & \text { no }-1 \mathrm{pt}\end{array}\end{array}$ \\
\hline 5 & $\begin{array}{l}\text { Is any periodic fertilization (using slurry or manure) performed, on cultivated land } \\
\text { neighbouring water intake? } \\
\begin{array}{ll}\text { yes }-3 \text { pt. } & \text { no }-1 \mathrm{pt}\end{array}\end{array}$ \\
\hline 6 & $\begin{array}{l}\text { Is sewage (e.g. from animal production) channelled to nearby watercourse on area } \\
\text { neighbouring water intake? } \\
\begin{array}{ll}\text { yes }-3 \text { pt. } & \text { no }-1 \mathrm{pt}\end{array}\end{array}$ \\
\hline 7 & 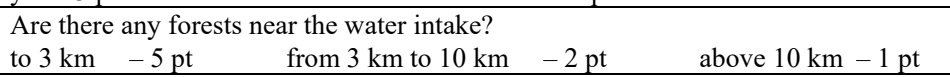 \\
\hline & \begin{tabular}{lll}
\multicolumn{3}{l}{ ification criteria for the level of exposure to agricultural danger: } \\
$\langle 7,13\rangle \quad$ low exposure to danger & $\mathrm{L}=1$ \\
$\langle 14,19\rangle$ & moderate exposure to danger & $\mathrm{M}=2$ \\
$\langle 20,32\rangle$ & high exposure to danger & $\mathrm{H}=3$
\end{tabular} \\
\hline
\end{tabular}


In the proposed method of analysis, the level of protection of WSS from random dangers was taken into the account, and it is inversely proportional to the value of the risk $r_{i}$. A reliable WSS protection system should consist of complex multi-layered security structure covering the entire system, from the catchment area to the consumers' tap. In order to improve, even more, the protection of water supply at the time of an undesirable event, an alternative method of supplying water should be also created. Such elements of protection system reduce the probability of occurrences of undesirable events and decrease their negative consequences. To assess the degree of protection in the WSS operating in agricultural areas a survey (Table 5) that takes different types of security into the account was developed. The data from the survey used along with eqn (4) shown below is a basic element required in order to estimate the degree of the protection in WSS.

$$
S=\sum_{i=1}^{6} S_{i}
$$

The aim of the second stage of the analysis is to determine the category of the total risk in WSS defined as: tolerated, controlled, unacceptable. This concerns only WSS that consist of at least three WSC. To assign those risk categories to WSS, a numerical value $r_{t}$ is calculated using eqn (5):

$$
r_{t}=\sum_{i=1}^{n} R_{i}
$$

where: $n-$ the number of all water supply circuits $(n \geq 3)$.

In this equation the $\mathrm{R}_{\mathrm{i}}$ values (Table 2) are used, as they represent the weight values of the risk $\mathrm{r}_{\mathrm{i}}$ that was previously determined for each WSC (eqn (1)).

In Table 6 , the classification of the total risk $r_{t}$ for the whole WSS built of 3 WSC is shown.

The following classification of the risk within the whole supply system applies for the systems built from more than three WSC:

- Tolerated risk: the value of the point scale

$$
\left\langle\left(L_{l, T}(3)+j\right) ;\left(\left(L_{l, C}(3)+(2 j-2)\right)\right\rangle\right.
$$

- Controlled risk: the value of the point scale

$$
\left\langle\left( L_{l, C}(3)+(2 j-1) ;\left(\left(L_{l, U A}(3)+(3 j-2)\right)\right\rangle\right.\right.
$$

- Unacceptable risk: the value of the point scale

$$
\left\langle\left( L_{l, U A}(3)+(3 j-1) ;\left(\left(L_{u p, U A}(3)+3 j\right)\right\rangle\right.\right.
$$

where: $j=n-3 ; n-$ number of WSC that together form a WSS; $L_{1, T}(3)-$ the lower limit of the tolerated risk, $\mathrm{L}_{1, \mathrm{C}}(3)$ - the lower limit of the controlled risk, $\mathrm{L}_{1, \mathrm{UA}}(3)$ - the lower limit of the unacceptable risk and $\mathrm{L}_{\mathrm{up}, \mathrm{UA}}(3)$ - the upper limit of the unacceptable risk. All limits listed here refer to WSS consisting of 3 WSC (Table 6).

The proposed research methodology, which allows for the categorization of the risk occurring in WSS in rural areas, is universal and thus can be adjusted for any WSC. Such adaptation can be achieved through the prior determination of significant factors influencing the occurrence of potential threats of agricultural origin. 
Table 5: The category of a water supply system protection from undesirable events.

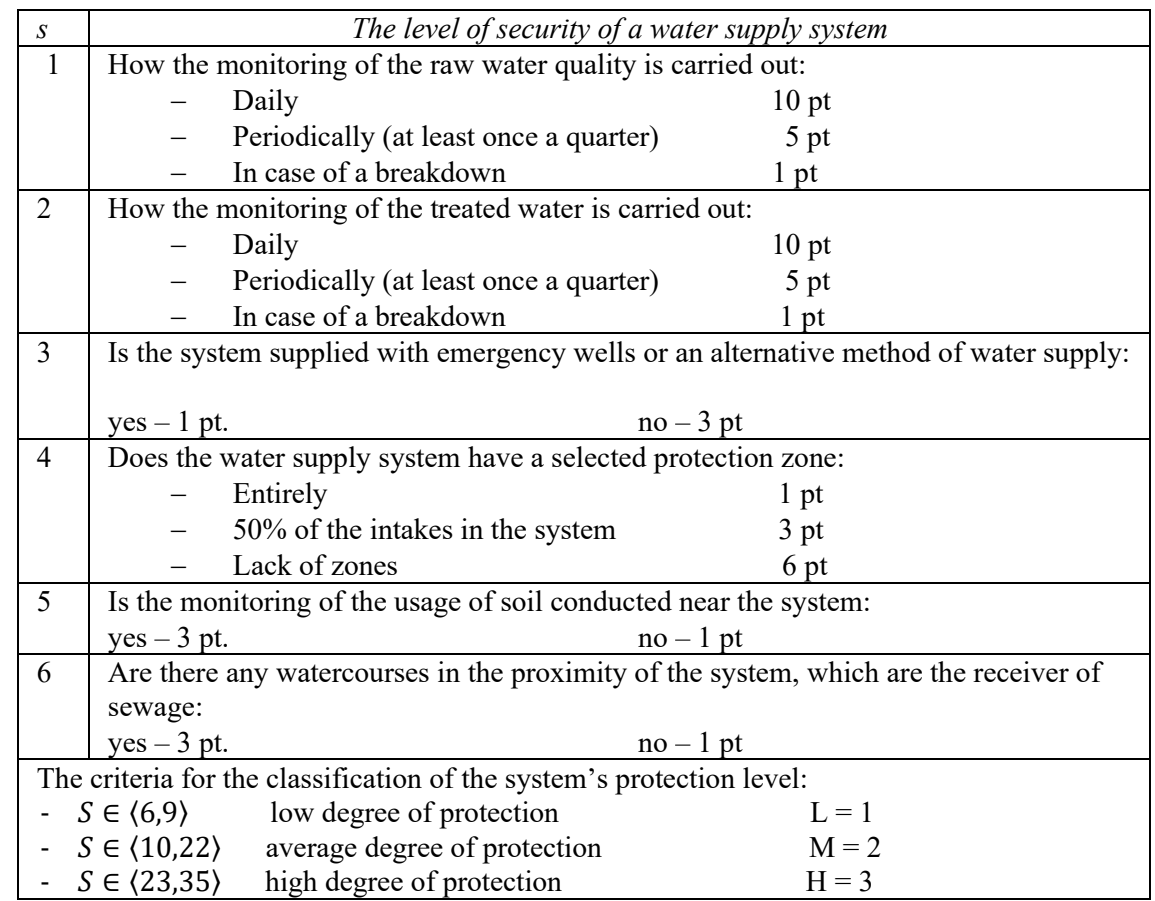

Table 6: The categories of the total risk for WSS built of 3 WSC.

\begin{tabular}{|ll|c|c|}
\hline \multirow{2}{*}{ The total risk category } & \multicolumn{2}{|c|}{ Point scale } \\
\cline { 3 - 4 } & Lower limit Ll (3) & Upper limit Lup (3) \\
\hline Tolerated & 3 & 4 \\
\hline Controlled & (C) & 5 & 6 \\
\hline Unacceptable (UA) & 7 & 9 \\
\hline
\end{tabular}

\section{BRIEF DESCRIPTION OF ANALYSES OF WATER SUPPLY SYSTEM}

The object of conducted study is a complex system of water supply to residents of Głubczyce, a county located in the Southern Poland. This system is made up of 4 independent municipal WSS, working on the basis of the several smaller water supply circuits exploiting groundwater resources (Table 7). Intensive development of the agricultural economy (agricultural, animal farming) in this area is the key threat to the quality of water delivered to consumers. This includes cultivation of crops, such as: potato, sugar beet, cereals which are carried by both the large farms, and individual farmers; but also animal breeding, where the most common is breeding of cattle (carried out by large farms). Moreover, the industrial breeding of poultry and swine is carried out in this area.

In the area of the research, 21 out of 33 water supply circuits in the county of Glubczyce are located directly on the land of agricultural use. These systems capture groundwater from a variety of depths, ranging from $2.5 \mathrm{~m}$ to $70 \mathrm{~m}$.

In the conducted assessment of the risk for 4 separate WSS, a six-year period of operation was adopted (years: 2010-2015). Over this study the data set was collected and includes 
Table 7: Characteristics of separated WSS in the county of Głubczyce.

\begin{tabular}{|c|c|c|c|c|c|}
\hline $\begin{array}{c}\text { Number } \\
\text { of WSC }\end{array}$ & $\begin{array}{c}\text { Length of pipe } \\
{[\mathrm{km}]} \\
\text { max; min; } \\
\text { average }\end{array}$ & $\begin{array}{c}\text { Daily water } \\
\text { production }\left[\mathrm{m}^{3} / \mathrm{day}\right] \\
\text { max; min; average }\end{array}$ & $\begin{array}{c}\text { The number } \\
\text { of inhabitants } \\
{[\text { thousands }]}\end{array}$ & $\begin{array}{c}\text { The } \\
\text { number } \\
\text { of intakes } \\
{[-]}\end{array}$ & $\begin{array}{c}\text { Depth range } \\
\text { of water } \\
\text { intake [m] }\end{array}$ \\
\hline 8 & $83.4 ; 0.7 ; 42.8$ & $783 ; 11 ; 490$ & 6.310 & 11 & $3.5-70$ \\
\hline \multicolumn{7}{|c|}{ WSS municipal Baborów } \\
\hline 5 & $100.6 ; 2.9 ; 36.3$ & $905 ; 35 ; 400$ & 6.590 & 11 & $3-30$ \\
\hline \multicolumn{7}{|c|}{ WSS municipal Głubczyce } \\
\hline 11 & $200.4 ; 0.2 ; 111.7$ & $3560.5 ; 1.5 ; 2900$ & 23.49 & 32 & $2.5-50$ \\
\hline \multicolumn{7}{|c|}{ WSS municipal Kietrz } \\
\hline 9 & $81.8 ; 1.0 ; 22.7$ & $1867.0 ; 6 ; 1300$ & 11.51 & 22 & $3-25$ \\
\hline
\end{tabular}

values of water quality parameters (raw and tap water), such as the nitrate concentration, number of coli bacteria, Escherichia Coli and the number of colonies at $22^{\circ} \mathrm{C}$. For better clarity the data set was put in order, in terms of water quality criteria intended for human consumption. The analysis of water quality was carried out by an accredited laboratory of the Regional Sanitary and Epidemiological Station in Opole using standard testing procedures.

The data concerning: the way in which the exploitation areas of certain WSS are used, the existing security protection in the intake zones, the level of deep wells exposure on the dangers of agricultural origin, number of residents and the costs of administrative proceedings was developed and analysed basing on the documentation of the technical administrators of each WSS.

\section{RESULTS AND DISCUSSION}

The collected data allowed for determination of the individual factors which were taken into account in the five-parameter risk matrix (P, E, C, F and S). Based on the value of partial risk $r_{i}$ established by the eqn (1), each of the 33 surveyed WSC was assigned to one of the risk categories (Table 2). In the next step of the research this categorization, along with the corresponding point values $\mathrm{R}_{\mathrm{i}}$, and eqn (5), allowed for determination of the total risk $r_{t}$ for each of the 4 WSS of Głubczyce county: WSS Baborów, WSS Branice, WSS Głubczyce and WSS Kietrz. The threshold ranges of various risks (tolerated, controlled and unacceptable Table 8) were determined from the formulas (6), (7), (8) as well as according to the research procedures.

The study clearly showed that for the three WSS located in the municipalities of Boborów, Branice and Kietrz the risk levels were 'controlled', thus justifying the need for risk management procedures. The factor that had a particular impact on the value of the risk $r_{i}$ for each WSC was the exposure to the agricultural danger. The operating conditions of WSS Głubczyce and its efficient system of protection against dangers of agricultural origin lead to the classification of its risk as tolerated.

For WSS Baborów risk values $r_{i}$ that were determined for each of its 8 WSC, were ranging from 2 to 12 . For $75 \%$ of them the risk was controlled, due to high levels of exposure to the dangers of the agricultural origin and the accompanying high probability of nitrates and microbiological parameters polluting water. For WSS Branice, risk was also classified as controlled. In this case, the controlled risk level was assigned to $80 \%$ of WSC. The factors with the strongest influence on the risk category were the size of the population exposed to 
Table 8: Total risk for 4 separate water supply systems in Głubczyce County.

\begin{tabular}{|l|c|c|c|c|}
\hline \multirow{2}{*}{ The category of risk } & \multicolumn{4}{|c|}{ WSS } \\
\cline { 2 - 5 } & Baborów & Branice & Glubczyce & Kietrz \\
\hline Point scale for tolerated risk & $\langle 8 ; 13\rangle$ & $\langle 5 ; 7\rangle$ & $\langle 11 ; 19\rangle$ & $\langle 9 ; 15\rangle$ \\
\hline Point scale for controlled risk & $\langle 14 ; 20\rangle$ & $\langle 8 ; 11\rangle$ & $\langle 20 ; 29\rangle$ & $\langle 9 ; 15\rangle$ \\
\hline Point scale for unacceptable risk & $\langle 21 ; 24\rangle$ & $\langle 12 ; 15\rangle$ & $\langle 30 ; 33\rangle$ & $\langle 9 ; 15\rangle$ \\
\hline $\begin{array}{l}\text { Number of WSC classified for the } \\
\text { tolerated risk }\end{array}$ & 2 & 1 & 8 & 2 \\
\hline $\begin{array}{l}\text { Number of WSC classified for the } \\
\text { controlled risk }\end{array}$ & 6 & 4 & 3 & 7 \\
\hline $\begin{array}{l}\text { Number of WSC classified for the } \\
\text { unacceptable risk }\end{array}$ & 0 & 0 & 0 & 0 \\
\hline The value of the total risk $r_{t}$ & 14 & 9 & 14 & 16 \\
\hline The category of the total risk & controlled & controlled & tolerated & controlled \\
\hline
\end{tabular}

potential risks as well as costs of financial consequences of the deterioration of water quality. The total risk $r_{t}$ for the largest WSS Głubczyce, was found to be in a tolerated category (Table 8). The study showed that for this system only $27 \%$ of WSC were at controlled risk. The WSS in Kietrz, reached the highest total risk $r_{t}$ value of 16 , what classified it in the controlled category. In this WSS the tolerated risk occurred for $22 \%$ of WSC. For the remaining $78 \%$ of WSC designated risk values classified as controlled due to high probability of deterioration of groundwater quality. This was a result of intensive activity in both cultivation of agricultural crops and animal breeding. In addition, during the six-year analysis, the system recorded high costs of removing the effects of deterioration in water quality.

\section{CONCLUSIONS AND RECOMMENDATIONS}

Matrix method was applied to risk analysis of water supply systems in rural areas. This methodology allows to evaluate and compare the levels of security for all WSS and to identify important factors posing the biggest danger to the water quality. Even though the matrix method is commonly used in risk analysis all over the world, the innovative approach in this study is the fact that the methodology is used particularly for WSS in rural areas where it hasn't been used yet.

Originally, in the analytical procedure a determination of the point weight risk (eqn (1)), associated with the security system and the exposure to dangers (S), as a variable inversely proportional to the size of the risk was included.

The determining factor of the risk category was the size of the population exposed to potential risks and costs of financial consequences of the deterioration of water quality.

\section{REFERENCES}

[1] Pietrucha-Urbanik, K., Rak, J. \& Tchórzewska-Cieślak, B., Safety analysis of water supply systems including protection barriers. Journal of Polish Safety and Reliability Association, 3(2), pp. 241-248, 2013.

[2] Chung, G., Lansey, K. \& Bayraksan, G., Reliable water supply system design under uncertainly. Environmental Modeling \& Soft, 24(4), pp. 449-462, 2009.

[3] Pereira, V.J., Water safety plans: methodologies for risk assessment and risk management in drinking-water system, CEC-HID 2005, Online. www.repositorium. sdum.uminho.pt/bitstream/1822/5092/1/interceltic_2005_J.Vieira.pdf 
[4] Coleman, M.E. \& Marks, H.M., Qualitative and quantitative risk assessment. Food Control. 10(4-5), pp. 289-297, 1999.

[5] WHO, Guidelines for Drinking-Water Quality. 3rd ed., Recommen.: Geneva, 2008. www.who.int/water_sanitation_health/en

[6] US EPA, A new approach to protecting drinking water and public health, Washington DC, 2010, Online. www.epa.gov/safewater

[7] Massarutto, A., Agricultural, water resource and water policies in Italy. EEM Working Paper, 33, pp. 1-24, 1999.

[8] Kunikane, S., Application of "Water Safety Plan" to drinking water quality management in Japan. US-Japan Governmental Conference, Okinawa, 2007. www.niph.go.jp/soshiki/suido/pdf/h19JPUS/abstract/r05.pdf

[9] Navalpotro, J.A.S., Perez, M.S. \& Quiroga, F.G., Water supply and water footprint in the urban region of Madrid (Spain). International Journal of Business and Social Science, 4(11), pp. 23-28, 2013.

[10] Oron, G., Campos, C., Gilleman, L. \& Salgot, M., Wastewater treatment, renovation and reuse for agricultural irrigation in small communities. Agricultural Water Management, 38(3), pp. 223-234, 1999.

[11] European Strategic Workshop on Water Safety Planning, European Strategic Workshop on Water Safety Planning, Berlin, 2014. http://www.umweltbundesamt. de/en/node/30590

[12] WHO, Water Safety in Distribution Systems, Public Health, Environmental and Social Determinants Water, Sanitation, Hygiene and Health, Geneva, 2014.

[13] Water Global Security, Water for all, water security in developing countries, MIT, http://12.000.scripts.mit.edu/mission2017/water-security-in-developing-countries/

[14] Rak, J., Selected problems of water supply safety. Environment Protection Engineering, 35(2), pp. 23-28, 2009.

[15] Rak, J. \& Pietrucha, K., Some factors of crisis management in water supply system. Environment Protection Engineering, 34(2), pp. 57-65, 2008.

[16] Hokstad, P. \& Røstum, J. (eds), Methods for risk analysis of drinking water system from source to tap. Guidance report on Risk Analysis. Techneau, Deliverable number D 4.2.4, pp. 47-75, 2009. www.techneau.org

[17] Mays, L.W., The role of risk analysis in water resources engineering. Journal of Contemporary Water Research and Education, 103(1), pp. 8-12, 1996.

[18] Rak, J. \& Tchórzewska-Cieślak, B., Review of Matrix Methods for risk assessment in water supply system. Journal of KONBiN, 1, pp. 67-76, 2006.

[19] Water Low (in Polish), Journal of Laws of 2015, item 2295. State sanitary inspection, gis.gov.pl/images/bw/stan_sanitarny_wps_2014.pdf 